中性子と研究炉

吉沢 英樹

（東京大学物性研究所 附属中性子科学研究施設）

1. 量子ビームの一つとしての中性子

いよいよ J-PARC/MLF において初中性子ビー ムが発生される時期が近づき，本誌でも J-PARC の進渉状況が，毎号つぶさに報告され，会員の期 待もピークを迎えつつあります。この原稿は 5 月 の連休に書いていますが, 原稿が掲載される7月 号には, 初ビーム発生のニュースを伝える記事が 賑々しく掲載されていることでしょう。

世界の趨勢は, 中性子ビームに限らず広く「量 子ビーム」の利用は基礎研究はもとより産業利用 から医療応用にまで拡大しつつあり, 著しい発展 期を迎えています。その詳しい状況については, 日本原子力研究開発機構 (JAEA) の柴田徳思先 生が日本物理学会誌の先月号 (2008 年 63 巻 4 月 号）に「放射線の工・農・医分野における利用之 その将来 ${ }^{1)} 」$ と題された記事で詳しく紹介されて います. なかでも医療応用における各種粒子線源 を応用した映像化技術は長足の進歩を遂げてい ます。陽電子断層撮影 (Positron Emission Tomography，いわゆる PET）もガンの診断に応用 されるようになり, 私たちの日常生活でも会話に のぼるほど，たいいん身近になってきました。

柴田先生の記事 ${ }^{1)}$ や参考文献 ${ }^{2)}$ によれば, PET 検査において陽電子を発生するために用いられ る核医学検査用 RI はフッ素 18 , 炭素 11 , 窒素 13 等です.これらはいずれも体を構成する元素 のアイソトープであり, 生体機能を担う化合物の 形で体の中に取り込ませた状態で映像化するこ とが可能です.このため生体機能が発現している 状態で人体の内部を撮影することが可能になり， 単なる元素の透過度の違いを応用寸る透過写真 による映像化手法とは大いに異なっています。こ の例は，なじみのあるX $\mathrm{X}$ 線を用いず，わざわざ 特殊な粒子線を発生させて利用寸る必要がなぜ あるのかを分かりやすく説明してくれる好例で す.

これを見倣って, 私も中性子散乱の講義を行う ときには, 中性子イメージングの例としてカーネ ーションの映像を学生と一緒に鑑賞することに しています. 図 1 亿東京大学大学院農学生命科学
系研究科の中西友子教授に提供していただいた 写真を示していますが, 花びら一枚ずつにいたる まで美しく写っている様は一幅の芸術作品のよ うであり, X 線イメージングとの相違は明らかで す.講義においては電子や陽子と比較して電荷や スピンなどの中性子の物理的性質の相違点を説 明することは必須です。しかし, なぜわざわざ原 子炉や加速器を用いてまで中性子を発生させて 研究に用いる必要があるのか直感的に理解して もらうためには, 映像の持つ訴求力は「百聞は一 見に如かず」のことわざ通り非常に強力です。

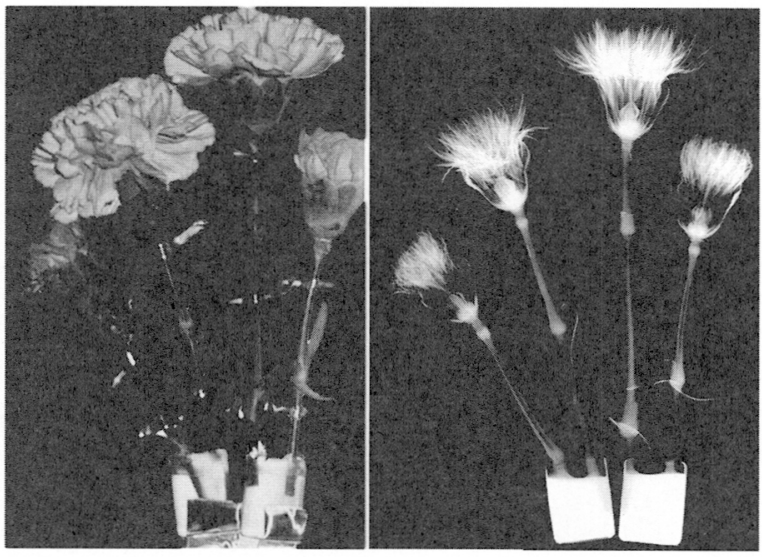

図 1.（右）カーネーションの中性子イメージング写真 (提供: 東京大学大学院農学生命科学研究科中西友子 教授)

現代では, 様々な粒子線がそれぞれ他にはない 利点を応用して活用されています。その中から， 中性子を用いて研究を行う意義を理解してもら うためには, 中性子の利点が明快に説明できなけ ればなりません。しかし，JCOの事故以来，中性 子に対して学生が持っているイメージはあまり 芳しくなく, 漠然と中性子は非常に危険なもの之 感じているようです。これに対しては，電磁波と 物質波を対比させることにより, 両者のエネルギ ースペクトルの相違を強調して, 放射線としての 生体への危険度の相違を説明します。そとさき， 両者が異なるエネルギースペクトルを持つこと は, 理科系の学生には当然理解していてもらいた 
い基礎知識ですが, 現状は必ずしもそうではあり ません，電磁波では，波長により様々な名称を持 つことから，様々なエネルギー（波長）により生 体への影響が異なることは理解されているので, 中性子も同様であることを強調しています.しか し, 名称一つとっても電磁波では一部ではありま すが「赤外線, 可視光, 紫外線」などと色のイメ ージを持つ名称が付与されているのに対して, 中 性子線の名称は「速, 熱外, 熱, 冷中性子」と温 度のイメージですので，かなり地味です，そうは いっても研究に使用する中性子はエネルギーが 十分低くて安全であることを理解してもらうに は，それなりに使える名称ではあります。

中性子散乱実験が安全であることを学生に説 明する際に，もう一つ悩ましいのが，あまりなじ みのない放射線量の単位です。ベクレル $(\mathrm{Bq})$, グレイ（Gy），シーベルト（Sv）になじむのは， 毎日放射線を取り扱っている私たちでも容易で はありませんでした. 放射線の利用が身近にあふ れている現代社会では, 人体一の影響の度合いを 表す実効線量だけは, 自分の身を守る意味でも, 数值レベルで理解しておくことがのぞましいと 思います。

例えば, 平成 19 年 7 月 16 日に発生した柏崎沖 地震では, 東京電力柏崎刈羽原子力発電所の 7 号 機の主排気筒から放射性物質が漏れたと報道さ れました. 東京電力が公表している情報 ${ }^{3)}$ によれ ば，そのときの放射線漏れは，7 月 24 日の発表 で $2 \times 10^{-4}$ マイクロシーベルト $(\mu \mathrm{Sv})$ でした.こ れが，一体どの程度の放射線量なのか，放射線取 扱者の講習を定期的に受けていなければ, 全く実 感がもてないであろうと思います. 私の例で恐縮 ですが，3 号炉で 4〜5 日の中性子散乱実験を行 うと, 数十マイクロシーベルト $(\mu \mathrm{Sv})$ の被爆量 があります。この数值を参考にすれば， 7 号機か らの放射線量は, 非常に微量であったことが分か ります。

ちなみに, 経済産業省資源エネルギー庁が編纂

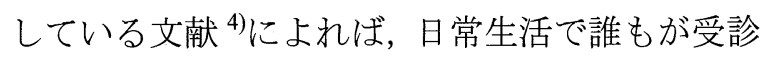
する健康診断の胸部 X 線撮影では 1 回の撮影で $50 \mu \mathrm{Sv}$, 胃の X 線集団検診では $600 \mu \mathrm{Sv}$ 被爆す るとされています. また, ニューヨークまで飛行 機で 1 回往復すると宇宙からの放射線を $200 \mu \mathrm{Sv}$ 程度浴びているそうです. 私は研究室に進学して きた学生に, 修士課程の研究を遂行する上で中性 子散乱実験による被爆量が, 具体的にどの程度の レベルのものかきちんと知っておいてもらうこ とを心がけています.これらの数值は誰もが経験 する事柄ですので, 中性子散乱実験による被爆を 研究リスクとして客観的に判断するための便利 な指標となっています. また, 遮蔽の知識も重要
ですので, 中性子は鉛では止められないこと, 逆 に, 鉛を使用すれば 2 次 $\gamma$ 線を発生させる 2 次放 射線源となってしまうので返って危険であるこ とも強調しています.

今後, 中性子散乱実験がますます盛んになるこ とにより, 全国の大学院の修士課程で正しい放射 線の知識を身につけた学生が多数社会に巣立つ ていくことも, 中性子散乱ができる社会貢献の一 つに数え上げておきたいものです.

\section{2. 研究炉は多目的炉}

この学会誌の読者には自明のことですが, 中性 子ビームを人工的に発生させるためには原子核 を破壊しなければなりません，RI にも中性子線 源として利用されている核種はありますが, 中性 子散乱が可能となる高密度の中性子束を持つ中 性子ビームを発生するためには, 原子炉か加速器 を用いる必要があります. 国内で中性子散乱実験 用の研究炬といえば JAEA の研究用 3 号炉 （JRR-3）ですが，この記事の冒頭でも述べたよ うに, 加速器線源の J-PARC/MLF でも中性子散乱 実験用の中性子ビームが発生されますから, 両者 の役割分担の議論は重要です. 様々な研究分野の 中性子散乱研究のニーズに対して, どちらの線源 とどのような分光器を用いるべきか学問的に正 しく把握した上で研究に用いられなければなり ません. 実際の研究の現場では, ハードマターの 研究においてもソフトマターの研究においても, 最も効率よくデータを測定することの出来る測 定法と分光器が選択され, それに従って定常ビー ムとパルスビームが使い分けられています。

しかし，このような定常ビームとパルスビーム の使い分けの議論は, あくまで中性子散乱実験か ら見た中性子ビーム利用の視点に限られており， 研究炉のすべての利用分野や利用形態を視野に 入れた議論ではありません. そのため, 中性子散 乱研究の視点からだけの一方的な議論では, 多目 的研究施設である研究炉の果たしている総合的 な意義を過小評価することになり, 大いに問題で あると, 私は個人的に感じています.

中性子ビーム利用に限ってみても, 研究炉は放 射化分析やラジオアイソトープの製造に用いら れており, 医療応用の研究も着実に進歩していま す.さらにもう一歩距離を置けば, 研究炉の存在 そのものが原子力の平和利用の流れの中に位置 付けられていることを忘れてはなりません.

それを踏まえて, 我が国の研究用原子炉の現状 をざっと見ておきましょう.いくつかの大学も研 究炉を所有していますが, 特に独立行政法人化以 降は大学が原子炉の維持管理を継続的に行って いくことが非常に困難になっています．そこで, 
国の科学技術政策を踏まえて研究用原子炉を運 営できる日本原子力研究開発機構（JAEA）に期 待される役割は，ますます高まっています.JAEA は多数の原子炉を所有して管理と運営を行って いますが，JAEAの施設共用制度の元で 4 基の研 究炉が学術研究と産業利用の外部利用のために 公開されています. それらをJAEAの産学連携推 進部の HPから表 1 にまとめてみました。

4 基の原子炉のらち 3 号炉（JRR-3）と 4 号师 （JRR-4）は東海地区にあり，JMTR 試験研究炉 と常陽（高速実験炉）は大洗地区にあります。3 号炉では中性子散乱実験装置の施設共用も主要 な部分を占めているので, 産学連携推進部は中性 子散乱実験装置に 1 行を割いていることが目を ひきます.

各研究炉の利用分野を見てみると, いずれの研 究炉も放射化分析，材料照射試験や RI の製造に 用いられています。これらの用途の需要は365日 絶え間なくありますが, 研究炉はあらかじめ決め られた利用運転計画に基づいて運転されていま すので, 1 基の研究炉だけでは, 切れ目無く需要 に対応することが出来ません，そのため, JAEA
では，3 基の研究炉の運転を総合的に組み合わせ て，例えば医療用 RI の需要に年間を通じて答え られる体制が取られています。

シリコン半導体の製造も研究炉の重要な用途 であることは, 中性子散乱研究者にはあまり知ら れていないかもしれません.Siインゴットを中性 子照射場の中に置くと Si 元素のアイソトープの 一つである ${ }^{30} \mathrm{Si}$ が ${ }^{31} \mathrm{P}$ に変換することを利用して P ドープシリコンがパワーデバイス用半導体と して製造されています（Neutron Transmutation Doping; NTD 法). P ドープシリコンの製造法に は様々な方法がありますが, 他の方法と比較して も NTD 法には十分なメリットがあるため，世界 では高品質のパワーデバイスの需要の高まりと ともに，NTD 法による製造が盛んになりつつあ ります。現在，世界の原子炉によるNTD 法によ る P ドープ Si インゴット（NTD-Si）の製造量は 年 170 トン程度ですが，そのうちの70\%は日本企 業によって消費されています。そこで, 表 1 の利 用欄に今は記載されていませんが，現在，NTD 法の利用を視野に入れて JMTR 試験研究炉の改 造が進められています。

・表 1 . 施設共用に提供されている JAEA の研究炉（産学連携推進部 HP から引用）

\begin{tabular}{|c|c|c|}
\hline \multicolumn{2}{|c|}{ 施設 } & 利用 \\
\hline$\frac{\text { JRR-3 研究炉 }}{\text { 東海地区 }}$ & 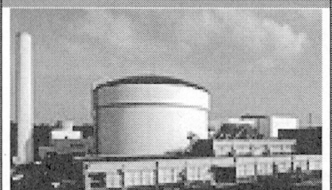 & $\begin{array}{l}\text {-放射化分析 } \\
\text {-原子炉用燃料 =材料照射 } \\
\text {-シリコン半導体の製造 } \\
\text {-ラジオアイソトープの製造 }\end{array}$ \\
\hline $\begin{array}{l}\frac{\mathrm{JRR}-3}{\text { 中性子ビーム実験装置 }} \\
\text { 東海地区 }\end{array}$ & 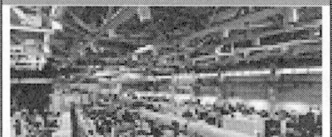 & $\begin{array}{l}\text { •中性子散乱実験 } \\
\text { •中性子ラジオグラフィ } \\
\text { ·中性子誘起即発ガンマ線分析 }\end{array}$ \\
\hline$\frac{\text { JRR-4 研究炉 }}{\text { 東海地区 }}$ & 파랑 & $\begin{array}{l}\frac{\text { ·放射化分析 }}{\text { ·材料照射 }} \\
\text { ·医療照射 } \\
\text { "ラジオアイソトープの製造 } \\
\text { ·教育訓練 }\end{array}$ \\
\hline $\begin{array}{l}\text { JMTR 試験研究炉 } \\
\text { 大洗地区 }\end{array}$ & 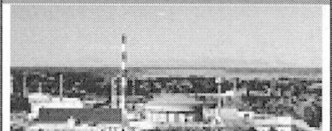 & $\begin{array}{l}\text { "原子炉用燃料·材料照射 } \\
\text { "ラジオアイソトープの製造 } \\
\text { ·照射後試験 }\end{array}$ \\
\hline $\begin{array}{l}\text { 常陽 高速実験炉 } \\
\text { 大洗地区 }\end{array}$ & & $\begin{array}{l}\text { - 原子炉用燃料=材料照射 } \\
\text { 照射後試験 }\end{array}$ \\
\hline
\end{tabular}


実は，3 号炉の性能は NTD 法に非常に適して おり, 現在 6 インチサイズの $\mathrm{Si}$ インゴットを照 射できる設備が稼働していて NTD-Si を毎年 4t ほど生産しています。これは国内における消費量 にくらべ供給量の点では, 著しく少ないと言わざ るをえませんが, 3 号炉は研究用原子炉ですから， 3 号炉が生産の主要部分を担う必要はありません. しかし, 今後の需要の増大を見こして, 食糧安保 と同様の意味で, 国内で生産できる技術力を維持 し,さらに技術開発を進めておくことは, 研究炉 の使命として, 誰もが納得できます. 3 号炉にお ける NTD-Si の開発研究は, 平成 19 年度から 3 力年計画で NEDO の研究課題に採択されていま す.これを梃子にJAEA の研究炉加速器管理部で は精力的な NTD-Si の技術開発を進めています. 他の原子炉では出せない特性を 3 号炉は出せま すので， 3 号炉で製造された高品質の NTD-Si に よるパワーデバイスが世界的な自動車メーカー の世界戦略車に限定搭載される日が近い将来訪 れることを，楽しみにしています。

研究炉の使命は, 基礎研究の推進であり特定の 分野の産業利用を推進することではありません が, 研究炉が提供する中性子ビーム, 中性子照射 場や RI は，研究炉でしか提供できません，たと え利用技術が確立していても，X線のように全国 ごこでも X 線源を購入して利用寸る訳にはいき ませんから, 非常に利用機会が限定されています. 従って, 貴重な研究炉の資源を有効利用するため の開発研究の一環として産業利用分野の利用研 究が含まれていることは, むしろ好ましい状況で す.

このように研究炉の利用分野は中性子散乱実 験以外にも多岐にわたっています。そそのため， 3 号炉と 4 号炉の利用者による「研究炉利用者㤅談 会」の会員には, 中性子散乱実験の研究者もいま すが, 照射・放射化分析・医療応用分野の利用者, そして原子炉技術を支えている原子力分野の研 究者と, 幅広い利用分野の研究者が大勢参加して います。 また，JAEA 側では施設共用に提供して いる 4 基の原子炉を総合的に運転することによ り, 幅広い研究炉利用分野のニーズに応えるべく, 適切な研究炉間の役割分担と連携協力を図って
います.このような研究炉の長年の学問分野への 貢献は, アメリカ原子力学会にもよく認知されて おり 3 号炉は昨年, 米国原子力学会から研究炉の 貢献を顕彰する賞である「ランドマーク賞」を授 与されました. 米国原子力学会長と日本原子力学 会長をお迎えして, その授与式と記念祝賀会が平 成 20 年 4 月 14 日に東海で盛大に執り行われたば かりです。

最後に, 3 号炉の中性子ビーム利用, 特に中性 子散乱実験の利用に戻りますが，ここ10 年ほど の中性子ビーム制御技術の進歩により，世界的に も原子炉の中性子分光器のイノベーションがブ 一ムになっています. 3 号炉を利用している中性 子散乱研究者の間でも, 分光器の高度化の検討が 精力的に行われていますので, その検討結果が, 近いうちに本誌でも紹介されることを期待して います。

参考文献

1. 柴田徳思 日本物理学会誌 2008 年 63 巻 4 月号 257 頁

2. 原子力がひらく世紀, 原子力学会編第 5 章 4 節

3. 東京電力の HP「新潟県中越沖地震に関寸る当社プ レスリリース等」欄の平成 19 年 7 月 24 日記事

4.「原子力 2005」経済産業省支援エネルギー庁編 